\title{
Effects of Rice Aging on Its Main Nutrients and Quality Characters
}

\author{
Bo Peng ${ }^{1}$, Lu-Lu He ${ }^{1}$, Jing Tan ${ }^{1}$, Li-Ting Zheng ${ }^{1}$, Jie-Ting Zhang ${ }^{1}$, Qian-Wen Qiao ${ }^{1}$, Ying Wang ${ }^{1}$, Yue Gao ${ }^{1}$, \\ Xia-Yu Tian ${ }^{1}$, Zi-Yue Liu ${ }^{1}$, Xiao-Hua Song ${ }^{2}$, Yan-Yang Sun ${ }^{1}$, Rui-Hua Pang ${ }^{1}$, Jin-Tao Li $^{1} \&$ Hong-Yu Yuan ${ }^{1}$ \\ ${ }^{1}$ College of Life Sciences and Institute for Conservation and Utilization of Agro-bioresources in Dabie Mountains, \\ Xinyang Normal University, Xinyang, China \\ ${ }^{2}$ Xinyang Academy of Agricultural Science, Xinyang, China \\ Correspondence: Bo Peng, College of Life Sciences and Institute for Conservation and Utilization of \\ Agro-bioresources in Dabie Mountains, Xinyang Normal University, Xinyang 464000, China. E-mail: \\ pengbo@xynu.edu.cn \\ Hong-Yu Yuan, College of Life Sciences and Institute for Conservation and Utilization of Agro-bioresources in \\ Dabie Mountains, Xinyang Normal University, Xinyang 464000, China. E-mail: yhongyu92@163.com
}

Received: June 16, 2019 Accepted: August 1, $2019 \quad$ Online Published: October 15, 2019

doi:10.5539/jas.v11n17p44 URL: https://doi.org/10.5539/jas.v11n17p44

\begin{abstract}
The main nutrients in rice are starch, protein and lipids, and their contents and physicochemical properties have important effects on rice qualities. The aging process of rice is very complex, which not only changes physical and chemical properties, but also changes its physiological characteristics in rice grain. In this paper, the changes of physicochemical properties of its main nutrients (starch, protein and lipids) during storage were reviewed. At the same time, the effects of rice aging on its quality characters and the mechanism of rice aging were also discussed, which could provide reference for solving the problem of rice quality decline during storage.
\end{abstract}

Keywords: rice aging, quality character, physicochemical properties, main nutritious substances

\section{Introduction}

Rice (Oryza sativa L.) is one of the most important food crops in the world. It is the staple food for more than 3 billion people in more than 100 countries and regions around the world, and rice provides more than $25 \%$ of the energy for more than half of the world's population (Peng et al., 2016a; Kusano et al., 2015). In China, more than two-thirds of the people live on rice (Peng et al., 2014a). Over the past decade, the total yield of rice had maintained a high level. A small amount of rice was used as raw materials for food processing and animal feed, most of which were directly grinded and processed for rice consumption. Therefore, rice needs to be stored for a period of time before consumption. During rice storage, the main nutrients (including starch, protein and lipids) of rice will undergo a series of changes in physical, chemical and physiological properties, which is aging (Zhou et al., 2016). Rice aging is a spontaneous process. With the prolongation of storage time, the color, gelatinization characteristics, flavor and composition of rice had changed (Sodhi et al., 2003). As a result, the nutritional quality, cooking and eating quality of rice will be changed, which will seriously affect the commercial value of rice in China. People in different countries have different choices of rice: consumers in China and Japan prefer to fresh rice, but Indians prefer to aged rice after storage (Gao et al., 2008). However, the mechanism of rice aging is still unclear. Therefore, it is of great theoretical significance and potential application prospects to discuss rice aging in depth.

Rice aging is a very complicated process. The storage of rice inevitably leads to its aging effect. As a result, the enzymatic activity of rice decreased, the respiratory ability decreased, and even the quality of rice deteriorated (Ziegler et al., 2017; Zhang et al., 2003). There are many factors affecting the aging of rice, including the changes of the main nutrients (such as protein, starch and lipids), the relative content of amylose and amylopectin, the changes of debranching enzymes, carbonyl compounds, sulfhydryl and carbonic acid, etc. External factors, including storage temperature, storage time, humidity and their interaction, were important factors affecting rice aging (Parnsakhorn et al., 2012; Faruq et al., 2015). Under the combined action of internal and external factors, the cell structure and chemical composition of rice would change during storage, and this change was simultaneous, interacting with each other and restricting each other (Guo et al., 2015). Thus, the physical and chemical properties, appearance quality, gelatinization performance, processing quality, cooking 
and eating quality of rice had changed significantly. Therefore, this paper summarized the changes of physicochemical properties of main nutrients during rice storage, and discussed the effects of rice aging on its quality characters, as well as the mechanism of rice aging, which will provide important reference for solving the problem of rice quality decline during storage.

\section{Effects of Rice Aging on Physicochemical Properties of Starch}

The main nutrients in rice are starch (including amylose and amylopectin), storage proteins and lipids, of which starch accounts for about 90\% of its dry weight (Peng et al., 2014a; Peng et al., 2018). The properties and contents of starch play an important role in rice quality traits. According to the content of amylose in rice grains, rice was divided into glutinous ( $0-2 \%)$ rice, low amylose (3-9\%) rice, low amylose (10-19\%) rice, medium amylose (20-25\%) rice and high amylose (more than 25\%) rice. After rice aging, the grain quality of rice would deteriorate obviously, which was mainly manifested in the decrease of stickiness, bad taste, lack of luster, loss of flavor and so on (Ahmed et al., 2016). During storage, a series of changes of starch in rice grains were the result of complex effects of many factors, which were related to rice varieties, maturity, water content, storage temperature and time (Zhou et al., 2016). During storage, the amylose content and structure of rice changed, which directly affected the sensory and cooking quality in rice.

It was generally believed that amylose content could affect grain quality in rice, especially cooking and eating quality traits, and the amylose content in rice grain was directly related to water absorption, swelling characteristics and cooking quality, as well as the cohesiveness, softness and luster of rice (Takahashi et al., 2017; Romero et al., 2018). The most obvious changes of rice grain during storage was the change of cooking and eating qualities, which were initially considered to be related to the changes of amylose contents (Wang et al., 2015). However, with the further study, it was found that the edible quality of different rice varieties containing similar amylose contents were different. Simulated storage test and amylose content determination of starch in some rice varieties with different aging degrees also confirmed that the total amylose contents of rice grains remained unchanged during storage (Casas et al., 2018; Abeysundara et al., 2015). Therefore, there are some limitations in evaluating the changes of rice grain during storage only from amylose content, and further analysis of starch structure is also needed.

The structure of starch has a great influence on the gelatinization temperature and aging properties of starch, and the fat contained in the spiral structure of starch also has a great influence on the gelatinization of starch. Studies have shown that amylose is easier to aging than amylopectin in rice storage. The aging speed and crystallinity of amylose vary with its own chain length (Hayashi et al., 2018; Villanueva et al., 2018). After the starch in rice was aged, it would precipitate very quickly. Even if it was heated again, the original structure would not be restored. This is because the molecules of amylose are not arranged in regular rows after rice aging, but are interlaced and densely packed together, thus forming a solid state which is insoluble in water but slightly soluble in alkali solution. At this time, the structure of starch was maintained by hydrogen bonds (Lee et al., 2014; Villanueva et al., 2018). Simultaneously, the starch debranching enzymes in rice itself could remove the branches on the surface of starch grains, thus making the starch grains become angular and blurred (Guleria et al., 2012). In the study of the relationship between insoluble amylose and the quality traits of stored rice, it was found that the cooking quality of rice deteriorated significantly with the increase of insoluble amylose content (Oh et al., 2018). The gelatinization temperature of rice starch increased with the prolongation of storage time, which showed that the gelatinization temperature of aged rice stored for 3.5 years was significantly higher than that of rice stored for 0.5 years. It was found that the dispersibility of aged rice starch in hot water was worse than that of new rice starch, excluding the effects of lipids and proteins (Zhang et al., 2017). This indicated that rice aging results in the strengthening of the structure of starch microcrystalline bundles, i.e. when water molecules infiltrate into the crystalline and amorphous regions of starch during heating, the expansion force was not enough to cause the structural breakdown and phase transfer of starch molecules with enhanced structure, resulting in the decrease of the degree of hot water dissolution during determination. Thus, this deterioration character was harmful to the cooking, eating and processing quality of rice grains.

Aging can decrease the proportion of amylopectin in total starch. Although the activity of amylase and amylase in rice decreased during storage, the content of longest chain component in amylopectin decreased due to the effects of debranching enzyme. Some of the branched chains were unbranched, and some of them might still retain a small number of branched points, which became smaller than the original ones. Some may become amylose fragments, some of which may also be colorless dextrin, thus reducing the content of total amylopectin. This was one of the reasons for the decrease of rice viscosity (Wei et al., 2012; Sasaki et al., 2018). In addition, the enhanced interaction between protein and starch also prevented starch from absorbing water, gelatinizing and polysaccharide free precipitation (Baxter et al., 2014). It may also be a factor leading to the decrease of viscosity 
and the increase of hardness of aged rice after cooking. The amylose and amylopectin contents of fresh rice stored at room temperature for 13 weeks did not changed significantly (Abeysundara et al., 2015). Starch content was considered to be an important index for predicting the edible and processing characteristics of rice grains. In particular, amylose was positively correlated with water absorption, volume expansion, fluffy degree and dispersity of rice grains, but negatively correlated with its viscosity, softness and color.

\section{Effects of Rice Aging on Physicochemical Properties of Storage Protein}

According to the function of protein in rice, it could be divided into storage protein, structural protein and protective protein (Shewry et al., 2002). Usually there are many kinds of structural proteins in rice, but the content of each structural protein is very small. Compared with other kinds of proteins, the storage protein content is higher, which is usually referred to as grain protein in rice, mainly referring to storage protein. The protein content in rice embryo was the highest, ranging from $16.8 \%$ to $24.1 \%$. The variation ranges of protein content in brown rice and milled rice were 5.1\% 15.4\% and 4.5\% 14.3\%, respectively (Chen et al., 2018; Juliao, 1972). According to the solubility of stored protein in rice grain and different methods of isolation and extraction, the grain stored proteins can be divided into four categories in rice: albumin, globulin, prolamin and glutenin (He et al., 2013). The storage proteins in rice endosperm were mainly glutenin and prolamin, of which glutenin was the most digestible protein, accounting for about $80 \%$ of the stored protein content in endosperm (Wang et al., 2009), The content of prolamin was about $10 \%$ (Kawakatsu et al., 2010b; He et al., 2013). The contents of albumin and globulin accounted for about $5 \%$ and $10 \%$ of the total protein content of rice, respectively (Shewry et al., 2002; Peng et al., 2014a). Overall, the protein content in rice ranges from $4.3 \%$ to $19.3 \%$ (Wroblewitz et al., 2014; Lu et al., 2009; Ye et al., 2010), providing about 15\% of the world's population with protein sources (He et al., 2013). Therefore, the stored protein in rice grains play an important role in its nutritional quality.

The results showed that the protein content of rice grain hardly changed during aging (Sowbhagya et al., 2001). Interestingly, protein content in rice was inversely proportional to its viscosity, and free amino acids in water increased with storage time (Tomic et al., 2015; Dhaliwal et al., 1991). It was also found that the lower molecular weight polypeptide decreased with the increase of storage time, while the higher molecular weight polypeptide increased (Park et al., 2012; Chrastil, 1990). More importantly, the content of acetic acid soluble protein in milled rice decreased during 7 years of storage (Bolling et al., 1977; Bolling et al., 1978; Mangrauthia et al., 2017). During the aging process, the protein content of rice grain changed slightly, but the soluble nitrogen decreased continuously. This is because the sulfhydryl groups of starch periphery proteins in rice oxidize into disulfide bonds under the combined action of light and heat in the air. Because of the formation of disulfide bond and the oxidation of lipids, the distance between peroxide and starch periphery proteins protected only by monolayer water film is shortened, which leads to the approximation and binding of proteins in rice, and then increases the crosslinking degree of disulfide bond of proteins, resulting in the decrease of solubility of proteins in rice. Protein forms a strong network around starch, which limited the expansion and softness of starch. Therefore, after cooking, the hardness of aged rice increased and its viscosity decreased (Jungtheerapanich et al., 2017; Dutta et al., 2012). Studies have shown that the total protein content of rice grain was basically unchanged during aging, but its extraction rate had decreased. It may be the binding of protein and starch increased (Yu et al., 2009; Sasaki, 2018). Whether albumin, globulin or glutenin, the content of high molecular weight subunits increased and that of low molecular weight subunits decreased after rice aging. Interaction between starch and protein of non-starch grains increased during rice aging, and the increased of this interaction may be one of the important reasons for the decreased of rice viscosity after aging (Jungtheerapanich et al., 2017). During rice storage, the extraction rate of protein showed a downward trend, which indicated that there was some interaction between starch and protein during rice storage. The existing research methods are to extract the components of rice first, and then study the interaction between the components. This interaction may not really reflect the interaction between the components of rice as a complete grain.

During the aging process of rice, the activities of $\alpha$-amylase and $\beta$-amylase decreased significantly, and the soluble protein content in rice also decreased. Alpha-amylase mainly concentrated in bran position of rice. Therefore, the content of $\alpha$-amylase in milled rice was very low, so the effects of $\alpha$-amylase on starch grains was very small. However, the exception was waxy milled rice, which contained more $\alpha$-amylase in endosperm, so it showed lower starch viscosity. The activities of protease, lipase and lipid oxidase increased during rice storage (Zhang et al., 2014). During rice storage, peroxidase and catalase decreased rapidly, because they were easy to be detected. Therefore, during rice storage in Japan, peroxidase and catalase are used as important indicators to evaluate rice quality deterioration. 


\section{Effects of Rice Aging on Physicochemical Properties of Lipids}

Lipids are very important nutrients in rice grains, including fat and phospholipids, which distribute in the aleurone layer outside the embryo and endosperm of rice seeds and form a complex between lipid and amylose (Xu et al., 2015; Goufo et al., 2014). Although lipids account for about 1\% of the total weight of rice, lipids were easily decomposed during rice aging, and free fatty acids were easily degraded by auto-oxidation or enzymatic oxidation (Narayana et al., 2010; Piggott et al., 1991). Therefore, there were many studies on the changes of lipids during rice aging in the early stage. These studies indicated that the rancidity of lipids was an important reason for the odor of aged rice. During the storage of rice, the lipids in rice are affected by air and high temperature, which can easily accelerate the deterioration rate of rice. Therefore, the change of lipids in rice is considered to be the main factor leading to the aging of rice grain.

There are two main ways to change lipids in rice grain: (1) Oxidation. Fatty acids in rice lipids are mostly unsaturated fatty acids, which can oxidize in air to produce carboxylic compounds, such as aldehydes and ketones. (2) Hydrolysis, in which lipase hydrolyzes the oil in rice to produce glycerol and fatty acids. Hydrolase played a decisive role in lipid oxidation and hydrolysis (Setimela et al., 2017; Zabed et al., 2017; Annor et al., 2016). During the aging process of rice, the decomposition rate of lipids was faster at high temperature than that of low temperature, and the decomposition rate of lipids was faster under high humidity than that of low humidity. Taking brown rice as an example, the content of lipids remained unchanged for 12 months at $5{ }^{\circ} \mathrm{C}$, but the content of lipids decreased significantly at $35^{\circ} \mathrm{C}$ (Table 1), especially the content of fatty acids (Zhou et al., 2002; Shin et al., 1986). Fatty acid value was one of the important indicators of quality change in rice storage. It is generally believed that the higher the fatty acid value, the worse the grain quality of rice (Fan et al., 2017). Therefore, the increase of free fatty acid content in rice after storage is the main reason for the deterioration of taste quality.

Table 1 Changes in lipid content of brown rice during storage (Zhou et al., 2002)

\begin{tabular}{|c|c|c|c|c|c|c|}
\hline \multirow{2}{*}{ Storage temp. $\left({ }^{\circ} \mathrm{C}\right)$} & \multirow{2}{*}{ Storage period (months) } & \multirow{2}{*}{ Lipid content $(\%)$} & \multicolumn{4}{|c|}{ Lipid fraction (\%) } \\
\hline & & & Neutral lipid & Glycolipid & Phospholipid & Free fatty acid \\
\hline \multirow{4}{*}{5} & 0 & 1.75 & 89.2 & 6.3 & 3.2 & 1.3 \\
\hline & 4 & 1.74 & 88.4 & 6.3 & 3.2 & 2.1 \\
\hline & 8 & 1.73 & 87.5 & 6.2 & 3.2 & 3.1 \\
\hline & 12 & 1.73 & 86.7 & 6.1 & 3.2 & 4.1 \\
\hline \multirow{4}{*}{35} & 0 & 1.75 & 89.2 & 6.3 & 3.2 & 1.3 \\
\hline & 4 & 1.70 & 84.5 & 6.1 & 3.2 & 6.3 \\
\hline & 8 & 1.68 & 82.5 & 6.1 & 3.1 & 8.4 \\
\hline & 12 & 1.65 & 81.7 & 5.9 & 3.0 & 9.4 \\
\hline
\end{tabular}

During the storage and aging of rice, the content of free fatty acids is increased by lipid hydrolysis. These free fatty acids and amylose form complex, and the complex molecules become spiral-like and dense crystallization, which limits the expansion of starch during cooking, makes rice hard and sticky, and affects the gelatinization of starch. Degreasing had little effect on cooking hardness and viscosity of rice after aging, but it had effects on the viscosity curve of rice flour paste, which decreased its viscosity value, refrigeration recovery value and maximum viscosity value (Tsai et al., 2012; Wiset et al., 2011). The experimental results showed that there was no obvious aging phenomenon after cooking rice treated with n-hexane and stored at $4 \sim 25{ }^{\circ} \mathrm{C}$ without lipids (Shu et al., 2014; Coudert et al., 2015). Free fatty acids produced by auto-oxidation of lipids in rice could wrap starch granules, thus increasing the strength of starch granules and making it difficult to gelatinize and absorb water, even after water absorption, it was not easy to crack (Yang et al., 2016; Choi et al., 2005). Therefore, rice aging will seriously affect the cooking and eating qualities of rice grain, making rice harder and less sticky.

Oleic acid and linoleic acid are the most important fatty acids in various lipid components. During rice aging, the absolute contents of free fatty acid, oleic acid and linoleic acid increased during storage, while triacylglycerol esters degraded during storage. Therefore, the peroxide value, free fatty acids and carbonyl groups of rice increased during storage (Figure 1) (Sun et al., 2011; Nishiba et al., 2000; Sowbhagya et al., 1976). Overall, the change of outermost layer of aged rice is more obvious, because this area is where non-starch components are relatively concentrated. Waxy rice tends to contain higher free fatty acids than non-waxy rice because it contains large amounts of non-starch lipids in endosperm. Starch lipids are not easily oxidized in storage as unsaturated 
fatty acids do, because they always maintain a constant fatty acid composition and content during storage. Therefore, the lipids involved in hydrolysis and oxidation are mainly non-starch lipids.

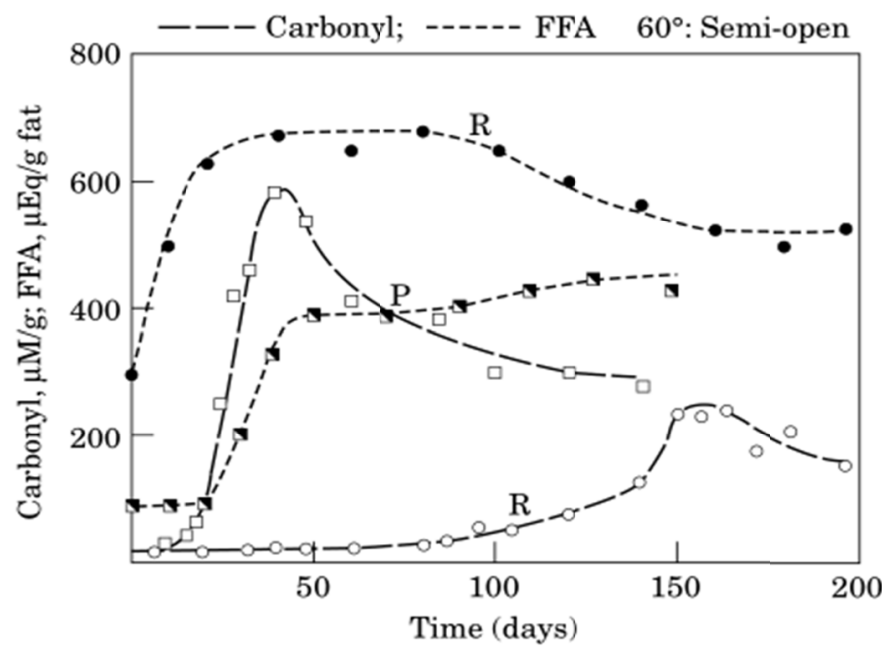

Figure 1. Changes in carbonyl (broken lines) and free fatty acid (dotted lines) contents in raw (R) and parboiled (P) rice on semi-open storage at $60^{\circ} \mathrm{C}$ in the dark (Zhou et al., 2002)

\section{Effects of Rice Aging on Grain Quality Characters}

During the aging process of rice grains, a series of physical and chemical changes have taken place along with the changes of main nutrients, as well as the effects of respiration, oxidation and enzymes of rice, resulting in a number of chemical changes for the grain quality characters in rice (Table 2) (Saikrishna et al., 2018). Aging could lead to the decline of cooking and eating qualities of rice grain, mainly in the hardness and viscosity of cooked rice (Kohyama et al., 2016; Ohno et al., 2007). The degree of decline in cooking and eating qualities of rice grain after aging was related to the external and internal factors affecting rice aging (Park et al., 2012; Jeongju et al., 2014). External factors mainly include temperature, humidity and other parameters in storage conditions and storage time; internal factors mainly include the damage of cell structure of rice grain itself and the change of chemical composition, among which the change of main chemical composition is the root cause of cell structure damage and physiological change. Studies have shown that the comprehensive eating quality of rice grain generally declined after 8 months of storage (Gondret et al., 2005; Koch et al., 1976). The contents of total protein and glutenin in rice grain were basically unchanged before and after aging, but the properties of glutenin changed significantly. After storage, total starch content decreased, amylose content increased and amylopectin content decreased (Osella et al., 2005; Hager et al., 2014). Although the content of lipids in rice is not much, it has a great influence on the food quality of rice grain and the aging of rice. Lipids in rice are easily hydrolyzed and oxidized due to the influence of oxygen in air and high temperature conditions, resulting in deterioration of grain quality in rice. It is generally believed that the safe fatty acid value of rice was $25 \mathrm{mg} \mathrm{KOH}$, and if it exceeded $25 \mathrm{mg} \mathrm{KOH}$, it was a signal of rice deterioration (Ponte et al., 2008; Walton et al., 2015). Fatty acid value has become the most important index of grain quality evaluation. Generally speaking, rice varieties with high extensibility are not easy to bond and break, and have better appearance. The swelling rate of rice is negatively correlated with taste and taste. The bigger the swelling rate of rice, the worse its quality (Daygon et al., 2016). In the rice soup with good quality, the blue color produced by starch and iodine is deeper, and the light transmittance is lower. When cooked, the rice soup is thicker and has the stickier rice. In contrast, the eating quality of aged rice became worse, the hardness of rice increased, but its viscosity decreased.

Free fatty acid content in aged rice increased with storage time (Zhang et al., 2011; Hu et al., 2014). The quality of brown rice with higher moisture content tended to deteriorate under high temperature storage, but the fatty acid value of brown rice increased sharply compared with that of new rice (Genkawa et al., 2008; Usman et al., 2014). After storing brown rice at room temperature for one year, the swelling rate of cooked rice increased, the viscosity of cooked rice decreased, the grain loosened and the rice yield increased (Parnsakhorn et al., 2012; Buggenhout et al., 2014). It is interesting to note that the cooking properties of brown rice, such as water absorption and expansion volume, vary greatly during high temperature storage (Charoenthaikij et al., 2009). Changes in cooking characteristics of brown rice showed that water absorption rate of brown rice increased after aging, while $\mathrm{pH}$ value 
of rice and solid content of rice soup decreased (Jeongju et al., 2014). During the storage of rice grain, although the content of starch has little change, the starch quality has changed in rice. Blue from starch and iodine turns light, light density decreases, light transmittance increases, and cooking and eating qualities deteriorates in rice.

In the process of rice storage, the increase or decrease of fatty acid content is often used as a sensitive index to determine the storage situation and the change of storage grain quality in rice. After aging, the generation of odor and the increase of acidity of rice are related to the changes of lipids. Therefore, the removal of non-starch lipids from brown rice can improve the storage stability of brown rice. If the degradation of lipids in rice grain was strictly controlled, the quality changes during storage and aging could be controlled. At the same time, the grain quality of rice could be ensured if the moisture content of rice grain was reduced below the safe moisture content and stored at low temperature. 
Table 2. Quality indices for monitoring of ageing of paddy/rice (Saikrishna et al., 2018)

\begin{tabular}{|c|c|c|c|}
\hline & Characteristics & Rice Varieties & Reference \\
\hline \multirow[t]{19}{*}{ Primary properties } & Textural characteristics & Milled rice & Zhou et al., 2002 \\
\hline & & Glutinous RD6 & Wiset et al., 2011 \\
\hline & & KDML 105 & Parnsakhorn et al., 2013 \\
\hline & & Hom Daeng & Tananuwong et al., 2011 \\
\hline & & Phitsanulok 2 & Le et al., 2014) \\
\hline & & Japonica type & Ohno, 2007 \\
\hline & & Phitsanulok 2 & Le et al., 2014 \\
\hline & & Q34 & Rosniyana et al., 2004 \\
\hline & Pasting behaviour & Japonica & Park et al., 2012 \\
\hline & & KDML 105 & Katekhong, 2012a, 2012b \\
\hline & & Hom Daeng & Tananuwong, 2011 \\
\hline & & Kyeema & Zhou et al., 2003 \\
\hline & & S701 & Sowbhagya, 2001 \\
\hline & & Phitsanulok 2 & Le et al., 2014 \\
\hline & Thermal characteristics & Makmurr 77 & Toe et al., 2000 \\
\hline & & KDML 105 & Katekhong, 2012a, 2012b \\
\hline & & Hom Daeng & Tananuwong, 2011 \\
\hline & & Kyeema & Zhou et al., 2010 \\
\hline & & Bengal & Fan and Marks, 1999 \\
\hline \multirow[t]{3}{*}{ Cooking quality } & Water absorption capacity & Q34 & Rosniyana et al., 2004 \\
\hline & Volume expansion & Q34 & Rosniyana et al., 2004 \\
\hline & Dissolved solids & Japonica type & Ohno, 2007 \\
\hline \multirow[t]{14}{*}{ Chemical composition } & Peroxide value & $\begin{array}{l}\text { Fajr, Tarom, Neda, Shafagh, Khazar, } \\
\text { Shiroudi, Nemat, and Lenjan }\end{array}$ & Bijanzadeh et al., 2016 \\
\hline & Free fatty acid & Brown rice (fresh and aged) & Shih et al., 2014 \\
\hline & Acidity & Rice & Zia-Ur-Rehman, 2006 \\
\hline & Protein content & Brown rice (fresh and aged) & Shih et al., 2014 \\
\hline & & Japonica type & Ohno, 2007 \\
\hline & Fat content & Brown rice (fresh and aged) & Shih et al., 2014 \\
\hline & Starch content & Brown rice (fresh and aged) & Shih et al., 2014 \\
\hline & Amylose content & Q34 & Rosniyana et al., 2004 \\
\hline & Starch granules & Brown rice (fresh and aged) & Shih et al., 2014 \\
\hline & Total soluble sugar & Rice & Zia-Ur-Rehman, 2006 \\
\hline & Total available lysine & & \\
\hline & Thiamine & & \\
\hline & Protein digestibility & & \\
\hline & Starch digestibility & & \\
\hline \multirow[t]{11}{*}{ Physical properties } & Water content (moisture) & Rice & Zia-Ur-Rehman, 2006 \\
\hline & Germination & Brown rice (fresh and aged) & Shih et al., 2014 \\
\hline & & $\begin{array}{l}\text { Fajr, Tarom, Neda, Shafagh, Khazar, } \\
\text { Shiroudi, Nemat, and Lenjan }\end{array}$ & Bijanzadeh et al., 2016 \\
\hline & Electrical conductivity & $\begin{array}{l}\text { Fajr, Tarom, Neda, Shafagh, Khazar, } \\
\text { Shiroudi, Nemat, and Lenjan }\end{array}$ & Bijanzadeh et al., 2016 \\
\hline & $\mathrm{pH}$ & $\begin{array}{l}\text { KDML 105, Chai Nat 1, Chai Nat 2, } \\
\text { Phitsanulok 2, San-pah-tawng and RD6 }\end{array}$ & Srikaeo et al., 2013 \\
\hline & & Brown rice (fresh and aged) & Shih et al., 2014 \\
\hline & & Rice & Zia-Ur-Rehman, 2006 \\
\hline & Peroxidase activity & $\begin{array}{l}\text { KDML 105, Chai Nat 1, Chai Nat 2, } \\
\text { Phitsanulok 2, San-pah-tawng and RD6 }\end{array}$ & Srikaeo et al., 2013 \\
\hline & Color & $\begin{array}{l}\text { KDML 105, Chai Nat 1, Chai Nat 2, } \\
\text { Phitsanulok 2, San-pah-tawng and RD6 }\end{array}$ & Srikaeo et al., 2013 \\
\hline & & Phitsanulok 2 & Le et al., 2014 \\
\hline & & Brown rice (fresh and aged) & Shih et al., 2014 \\
\hline
\end{tabular}

\section{Conclusion}

The aging process of rice grain is very complex, which not only changes its physical and chemical properties, but also changes its physiological characteristics. The main nutrients in rice grain are starch, protein and lipids, and their contents and physicochemical properties change with the aging process of rice, which has an important 
impact on many grain quality characters in rice. In the process of rice storage, if the degradation of lipids in rice grains can be strictly controlled, reduced moisture content in rice to below safe moisture content, and the rice grains stored at low temperature room, all of these measures are of great significance for ensuring the grain quality of rice.

\section{Acknowledgements}

This work was financially supported by National Natural Science Foundation of China (U1604110, 31600992, 31801332), Key Scientific and Technological Research Projects in Henan Province (182102110442, 192102110119), Special Research Project of Teacher Education Linkage Development Community in Southern Henan (2019-GTTYB-01), Research Project of Teacher Education Curriculum Revolution of XYNU (2019-JSJYYJ-10), Nanhu Scholars Program for Young Scholars of XYNU (2016056), Scientific Research Innovation Project for Postgraduate of XYNU (2018KYJJ47), Key Scientific Research Projects of Universities in Henan Province (19A180030), Institute for Conservation and Utilization of Agro-bioresources in Dabie Mountains.

\section{References}

Abeysundara, A. T., Navaratne, S. B., \& Wickramasinghe, I. (2015). Determination of changes occurrence in important physical properties of paddy during early storage. Journal of International Science Research, 6, 2094-2097. https://doi.org/10.1071/ZO14058

Ahmed, W., Butt, M. S., \& Sharif, M. K. (2016). Effect of storage on cooking quality attributes and fortificants stability in edible-coated iron-folate fortified basmati rice. Journal of Food Processing \& Preservation, 40(5), 925-933. https://doi.org/10.1111/jfpp.12671

Annor, B., \& Badu-Apraku, B. (2016). Gene action controlling grain yield and other agronomic traits of extra-early quality protein maize under stress and non-stress conditions. Euphytica, 212(2), 213-228. https://doi.org/10.1007/s10681-016-1757-4

Baxter, G., Blanchard, C., \& Jian, Z. (2014). Effects of glutelin and globulin on the physicochemical properties of rice starch and flour. Journal of Cereal Science, 60(2), 414-420. https://doi.org/10.1016/j.jcs.2014.05.002

Bolling, H., Hampel, G., \& Elbaya, A. W. (1977). Changes in physical and chemical characteristics of rice during prolonged storage. Riso, 26, 65-69. https://doi.org/10.1080/07373937.2012.710692

Bolling, H., Hampel, G., \& Elbaya, A. W. (1978). Studies on storage of milled rice for a long period. Food Chemistry, 3, 17-22. https://doi.org/10.1016/0308-8146(78)90043-2

Buggenhout, J., Brijs, K., Oevelen, J. V., \& Delcour, J. A. (2014). Milling breakage susceptibility and mechanical properties of parboiled brown rice kernels. LWT-Food Science and Technology, 59(1), 369-375. https://doi.org/10.1016/j.lwt.2014.05.001

Bijanzadeh, E., Naderi, R., Nosrati, K., \& Egan, T. P. (2017). Effects of accelerated ageing on germination and biochemistry of eight rice cultivars. Journal of Plant Nutrition, 40, 156-164. https://doi.org/10.1080/ 01904167.2016.1201502

Casas, G. A., Overholt ,M. F., Dilger, A. C., Boler, D. D., \& Stein, H. H. (2018). Effects of full fat rice bran and defatted rice bran on growth performance and carcass characteristics of growing-finishing pigs. Journal of Animal Science, 96(6), 2293-2309. https://doi.org/10.1093/jas/sky145

Charoenthaikij, P., Jangchud, K., \& Jangchud, A. (2009). Germination conditions affect physicochemical properties of germinated brown rice flour. Journal of Food Science, 74(9), 658-665. https://doi.org/ $10.1111 / \mathrm{j} .1750-3841.2009 .01345 . \mathrm{x}$

Chen, P. L., Shen, Z. K., Ming, L. C., Dan, W. H., Lou, G. M., Peng, B., ... He, Y. Q. (2018). Genetic basis of variation in rice seed storage protein (albumin, globulin, prolamin, and glutelin) content revealed by genome-wide association analysis. Frontiers in Plant Science, 9, 612. https://doi.org/10.3389/ fpls.2018.00612

Choi, H. W., Koo, H. J., Kim, C. T., \& Hwang, S. Y. (2005). Physicochemical properties of hydroxypropylated rice starches. Korean Journal of Food Science \& Technology, 37(1), 44-49.

Chrastil, J. (1990). Chemical and physicochemical changes of rice during storage at different temperatures. Journal of Cereal Science, 11, 71-85. https://doi.org/10.1016/S0733-5210(09) 80182-3 
Coudert, Y., Le, V. A., Adam, H. Bes, M., Vignols, F., Jouannic, S., ... Gantet, A. (2015). Identification of CROWN ROOTLESS1-regulated genes in rice reveals specific and conserved elements of postembryonic root formation. New Phytologist, 206(1), 243-254. https://doi.org/10.1111/nph. 13196

Daygon, V, D., Prakash, S., Calingacion, M., Riedel, A., Ovenden, B., Snell, P., ... Fitzgerald, M. (2016). Understanding the jasmine phenotype of rice through metabolite profiling and sensory evaluation. Metabolomics, 12(4), 1-15. https://doi.org/10.1007/s11306-016-0989-6

Dhaliwal, Y., Sekhon, K., \& Nagi, H. (1991). Enzymatic activities and rheological properties of stored rice. Cereal Chemistry, 68(1), 18-21. https://doi.org/10.1021/bp00007a013

Dutta, H., \& Mahanta, C. L. (2012). Effect of hydrothermal treatment varying in time and pressure on the properties of parboiled rices with different amylose content. Food Research International, 49(2), 655-663. https://doi.org/10.1016/j.foodres.2012.09.014

Fan, F., Li, Y. J., \& Qiu, X. L. (2017). Changes in rice grain quality of indica and japonica type varieties released in China from 2000 to 2014. Frontiers in Plant Science, 8, 1863. https://doi.org/10.3389/fpls.2017.01863

Fan, J., \& Marks, B. P. (1999). Effects of rough rice storage conditions on gelatinization and retrogradation properties of rice flours. Cereal Chemistry, 76(6), 894-897. https://doi.org/10.1094/CCHEM.1999.76.6.894

Faruq, G., Prodhan, Z. H., \& Nezhadahmadi, A. (2015). Effects of ageing on selected cooking quality parameters of rice. International Journal of Food Properties, 18(4), 922-933. https://doi.org/10.1080/10942912. 2014.913062

Gao, Y. L., Jv, X. R., Yao, M. L., \& Wu, D. (2008). Study on aging mechanism of rice during storage. Food Science, 29(4), 470-473. https://doi.org/1002-6630(2008)04-0470-04

Genkawa, T., Uchino, T., Inoue, A., Tanaka, F., \& Hamanaka, D. (2008). Development of a low moisture-content storage system for brown ricw: to rability decreased moisture contents. Biosystems Engineering, 99, 515-522. https://doi.org/10.1016/j.biosystemseng.2007.12.011

Gondret, F., Combes, S., \& Lefaucheur, L. (2005). Effects of exercise during growth, and alternative rearing systems on muscle fibers, and collagen properties. Reproduction Nutrition Development (EDP Sciences), 45(1), 69-86. https://doi.org/10.1051/rnd:2005003

Goufo, P., Kratz, S., \& Rosa, E. A. S. (2014). Effect of elevated carbon dioxide concentration on rice quality: nutritive value, color, milling, cooking, and eating qualities. Cereal Chemistry, 91, 513-521. https://doi.org/10.1094/CCHEM-12-13-0256-R

Guleria, S., Sharma, V., \& Marathi, B. (2012). Molecular mapping of grain physico-chemical and cooking quality traits using recombinant inbred lines in rice (Oryza sativa L.). Journal of Plant Biochemistry \& Biotechnology, 21(1), 1-10. https://doi.org/10.1007/s13562-011-0064-3

Guo, Y., Cai, W., Tu, K., Wang, S., \& Zhu, X. (2015). Key proteins causing changes in pasting properties of rice during aging. Cereal Chemistry, 92, 384-388. https://doi.org/10.1094/CCHEM-05-14- 0104-R

Hager, A, S., Bosmans, G, M., \& Delcour, J, A. (2014). Physical and molecular changes during the storage of gluten-free rice and oat bread. Journal of Agricultural and Food Chemistry, 62(24), 5682-5689. https://doi.org/10.1021/jf502036x

Hayashi, M., Crofts, N., \& Oitome, N. F. (2018). Analyses of starch biosynthetic protein complexes and starch properties from developing mutant rice seeds with minimal starch synthase activities. BMC Plant Biology, 18(1), 59. https://doi.org/10.1186/s12870-018-1270-0

He, Y., Wang, S., \& Ding, Y. (2013). Identification of novel glutelin subunits and a comparison of glutelin composition between japonica and indica rice (Oryza sativa L.). Journal of Cereal Science, 57, $362-371$. https://doi.org/10.1016/j.jcs.2012.12.009

Hu, J. L., Nie, S. P., Li, N., Min, F. F., Li, C., D., \& Xie, M, Y. (2014). Effect of gum arabic on glucose levels and microbial short-chain fatty acid production in white rice porridge model and mixed grain porridge model. Journal of Agricultural and Food Chemistry, 62(27), 6408-6416. https://doi.org/10.1021/jf501557b

Juliao, B. O. (1972). Physicochemcal properties of starch and protein in relation to grain quality and nutritional value of rice. Rice Breeding, 5, 389-405. https://doi.org/10.2135/cropsci1972.0011183X001200020018x 
Jungtheerapanich, S., Tananuwong, K., \& Anuntagool, J. (2017). Aging kinetics of low amylose rice during storage at ambient and chilled temperatures. International Journal of Food Properties, 20(8), 1904-1912. https://doi.org/10.1080/10942912.2016.1223127

Katekhong, W., \& Charoenrein, S. (2012a). The effect of rice aging on the freeze e thaw stability of rice flour gels. Carbohydrate Polymers, 89, 777-782. https://doi.org/10.1016/j.carbpol.2012.04.007

Katekhong, W., \& Charoenrein, S. (2012b). Effect of rice storage on pasting properties, swelling and granular morphology of rice flour. Asian Journal of Food Agro-Industry, 5, 135-140. https://doi.org/10.1002/ star.201100204

Kawakatsu, T., Hirose, S., Yasuda, H., \& Takaiwa, F. (2010). Reducing rice seed storage protein accumulation leads to changes in nutrient quality and storage organelle formation. Plant Physiology, 154, 18421854. https://doi.org/10.2307/25758723

Kim, J. J., Baek, M. K., Kim, K. S., \& Yoon M. R. (2014). Changes of physicochemical properties and fatty acid compositions of rough rice stored at different storage temperatures and periods. Korean Journal of Cropence, 59(4), 413-426. https://doi.org/10.7740/kjcs.2014.59.4.413

Koch, R, M., Dikeman, M, E., \& Crouse, J, D. (1976). Characterization of biological types of cattle (cycle III), carcass composition, quality and palatability. Journal of Animal Science, 48(6), 1160-1168. https://doi.org/ $10.2527 / \mathrm{jas} 1978.4751022 \mathrm{x}$

Kohyama, K., Sodhi, N, S., \& Suzuki, K., (2016). Texture evaluation of cooked rice prepared from japanese cultivars using two-bite instrumental test and electromyography. Journal of Texture Studies, 47(3), 188-198. https://doi.org/10.1111/jtxs.12172

Le, T. Q., Songsermpong, S., Rumpagaporn, P., Suwanagul, A., \& Wallapa, S. (2014). Mi-crowave heating for accelerated aging of paddy and white rice. Australian Journal of Crop Science, 8, 1348-1358. https://doi.org/ 10.1111/j.1745-4557.2010.00366.x

Lee, H. J., Jee, M. G., Kim, J., Nogoy, F. M., Nino, M. J., Yu, A. D., ... Cho, Y. G. (2014). Modification of starch composition using RNAi targeting soluble starch synthase I in japonica rice. Plant Breeding \& Biotechnology, 2, 301-312. https://doi.org/10.9787/PBB.2014.2.3.301

Lu, K., Li, L., Zheng, X., Zhang, Z., Mou, T., \& Hu, Z. (2009). Genetic dissection of amino acid content in rice grain. Journal of the Science of Food and Agriculture, 89, 2377-2382. https://doi.org/10.1002/jsfa.3731

Luo, Z. Y., Ren, Y. P., Xiao, H. Z., Tang, W. M. (2004). Study on the storability of brown rice and start the project of brown rice storage in China. China Rice, 2, 34-36. https://doi.org/10.3969/j.issn.1006-8082. 2004.02.016

Mangrauthia, S. K., Bhogireddy, S., Agarwal, S., Prasanth, V. V., Voleti, S. R., Neelamraju, S., \& Subrehmanyam, D. (2017). Genome-wide changes in microRNA expression during short and prolonged heat stress and recovery in contrasting rice cultivars. Journal of Experimental Botany, 68(9), 2399-2412. https://doi.org/ $10.1093 / \mathrm{j} x \mathrm{~b} / \mathrm{erx} 111$

Narayana, R. M., Viswanatha, T., Mathur, P. B., \& Swaminathan. (2010). Effect of storage on the chemical composition of husked, undermilled and milled rice. Journal of the Science of Food \& Agriculture, 5(9), 405-409. https://doi.org/10.1002/jsfa.2740050903

Nishiba, Y., Sato, T., \& Suda, I. (2000). Convenient method to determine free fatty acid of rice using thin-layer chromatography and flame-ionization detection system. Cereal Chemistry, 77, 223-229. https://doi.org/ 10.1094/CCHEM.2000.77.2.223

Oh, I. K., Bae, I. Y., \& Lee, H. G. (2018). Complexation of high amylose rice starch and hydrocolloid through dry heat treatment: Physical property and in vitro starch digestibility. Journal of Cereal Science, 79, 341-347. https://doi.org/10.1016/j.jcs.2017.11.017

Ohno, T., Tomatsu, M., Toeda, K., \& Ohisa, N. (2007). Texture of cooked rice prepared from aged rice and its improvement by reducing agents. Bioscience Biotechnology and Biochemistry, 71, 2912-2920. https://doi.org/10.1271/bbb.70279

Osella, C, A., Hugo, D, S., \& Carrara, C, R. (2005). Water redistribution and structural changes of starch during storage of a gluten-free bread. Starch, 57(5), 208-216. https://doi.org/10.1002/star. 200400330 
Park, C. E., Kim, Y. S., Park, K. J., \& Kim, B. K. (2012). Changes in physicochemical characteristics of rice during storage at different temperatures. Journal of Stored Products Research, 48, 25-29. https://doi.org/ 10.1016/j.jspr.2011.08.005

Parnsakhorn, S., \& Noomhorm, A. (2012). Effects of storage temperature on physical and chemical properties of brown rice, parboiled brown rice and parboiled paddy. Thai Journal of Agricultural Science, 45(4), 221-231. https://doi.org/10.5993/AJHB.39.3.12

Parnsakhorn, S., \& Langkapin, J. (2013). Changes in physicochemical characteristics of germinated brown rice and brown rice during storage at various temperatures. Agricultural Engineering International: The CIGR Journal, 15, 293-303. https://doi.org/10.5993/AJHB.39.3.12

Peng, B., Kong, H. L., Li, Y. B., Wang, L. Q., Zhong, M., Sun, L., ... He, Y. Q. (2014). OsAAP6 functions as an important regulator of grain protein content and nutritional quality in rice. Nature Communications, 5, 4847. https://doi.org/10.1038/ncomms5847

Peng, B., Peng, Y., Peng, J., Kong, D. Y., He, L. L., Sun, Y. F., ... Song, S. Z. (2018). Research advancement and prospects of main nutritious substances synthesis and regulation in rice seeds. Chinese Journal of Tropical Crops, 39(6), 1241-1251. https://doi.org/10.3969/j.issn.1000-2561. 2018.06.030

Piggott, J. R., Morrison, W. R., \& Clyne, J. (1991). Changes in lipids and in sensory attributes on storage of rice milled to different degrees. International Journal of Food Science and Technology, 26(6), 615-628. https://doi.org/10.1111/j.1365-2621.1991.tb02007.x

Ponte, P. I., Alves, S. P., Bessa, R. J., Ferreira, L. M., Gama, L. T., Bras, J. L., ... Prates, J. A. (2008). Influence of pasture intake on the fatty acid composition, and cholesterol, tocopherols, and tocotrienols content in meat from free-range broilers. Poultry Science, 87(1), 80-88. https://doi.org/10.3382/ps.2007-00148

Romero-Bastida, C. A., Miguel, C. G., Luis, A., \& Bello, P. (2018). Rheological properties of nanocomposite-forming solutions and film based on montmorillonite and corn starch with different amylose content. Carbohydrate Polymers, 188, 121-127. https://doi.org/10.1016/j.carbpol.2018.01.089

Rosniyana, A., Hashifah, M. A., \& Shariffah Norin, S. A. (2004). Effect of heat treatment (accelerated ageing) on the physicochemical and cooking properties of rice at different moisture contents. Tropic Agricultural and Food Science, 32, 155-162. https://doi.org/10.1080/10942912.2014. 913062

Saikrishna, A., Sayantani, D., \& Vijayalakshmi, S. (2018). Ageing of rice: a review. Journal of Cereal Science, 81, 161-170. https://doi.org/10.1016/j.jcs.2018.04.009

Sasaki, T. (2018). Effects of xanthan and guar gums on starch digestibility and texture of rice flour blend bread. Cereal Chemistry, 95(1), 177-184. https://doi.org/10.1002/cche.10024

Setimela, P. S., Gasura, E., \& Tarekegne, A. T. (2017). Evaluation of grain yield and related agronomic traits of quality protein maize hybrids in Southern Africa. Euphytica, 213(12), 289. https://doi.org/10.1007/ s10681-017-2082-2

Shewry, P. R., \& Halford, N. G. (2002). Cereal seed storage proteins: Structures, properties and role in grain utilizeation. Journal of Experimental Botany, 53, 947-958. https://doi.org/10.1023/a:1020663916259

Shih, C. H., Lee, T. T., Kuo, W. H. J., \& Yu, B. (2014). Growth performance and intestinal microflora population of broilers fed aged brown rice. Annals. Animal. Science, 14, 897-909. https://doi.org/10.2478/ aoas-2014-0048

Shin, M. G., Yoon, S. H., Rhee, J. S., \& Kwon, T. W. (1986). Correlation between oxidative deterioration of unsaturated lipid and hexanal during storage of brown rice. Journal of Food Science, 51(2), 460-463. https://doi.org/10.1111/j.1365-2621.1986.tb11155.x

Shu, J., Liu, D., \& Jiang, T. (2014). The study for the ultrasonic mechanism on accelerating rice wine aging. Journal of Chinese Institute of Food Science and Technology, 14(5), 43-48. https://doi.org/10.1111/ jfpp. 12629

Sowbhagya, C. M., \& Bhattacharya, K. R. (1976). Lipid autoxidation in rice. Food Science and Technology, 41, 1018-1023. https://doi.org/10.1111/j.1365-2621.1976.tb14380.x

Sowbhagya, C. M., \& Bhattacharya, K. R. (2001). Changes in pasting behaviour of rice during ageing. Journal of Cereal Science, 34(2), 115-124. https://doi.org/10.1006/jcrs.2001.0371 
Sun, Y. E., Wang, W. D., Chen, H. W., \& Li, C. (2011). Autoxidation of unsaturated lipids in food emulsion. Critical Reviews in Food Science and Nutrition, 51(5), 453-466. https://doi.org/10.1080/1040839100 3672086

Srikaeo, K., \& Panya, U. (2013). Efficiencies of chemical techniques for rice grain freshness analysis. Rice Science, 20, 292-297. https://doi.org/10.1016/S1672-6308(13)60144-4

Takahashi, T., \& Fujita, N. (2017). Thermal and rheological characteristics of mutant rice starches with widespread variation of amylose content and amylopectin structure. Food Hydrocolloids, 62, 83-93. https://doi.org/10.1016/j.foodhyd.2016.06.022

Tananuwong, K., \& Malila, Y. (2011). Changes in physicochemical properties of organic hulled rice during storage under different conditions. Food Chemistry, 125, 179-185. https://doi.org/10.1016/j.foodchem. 2010.08.057

Teo, C. H., Abd-Karim, A., Cheah, P. B., Norziah, M. H., \& Seow, C. C. (2000). On the roles of protein and starch in the aging of non-waxy rice flour. Food Chemistry, 69, 229-236. https://doi.org/10.1016/ S0308-8146(99)00271-X

Tomic, J., Torbica, A., Popovic, L., \& Strelee, L. (2015). Albumins characterization in relation to rheological properties and enzymatic activity of wheat flour dough. Journal of Agricultural Science \& Technology, 17(4), 805-816. https://doi.org/hdl.handle.net/123456789/3875

Tsai, C. L., Sugiyama, J., Shibata, M., Kokawa, M., Fujita, K., Tsuta, M., ... Araki, T. (2012). Changes in the texture and viscoelastic properties of bread containing rice porridge during storage. Bioscience, Biotechnology and Biochemistry, 76(2), 331-335. https://doi.org/10.1271/bbb.110722

Usman. A., Sutrisno, Y., Aris P., Wayan B., Yoshio M., Seiichi, O., ... Dwi, D. N. (2014). Prediction of hardness development in mangosteen peel using NIR spectroscopy during low temperature storage. Engineering in Agriculture, Environment and Food, 7(2), 86-90. https://doi.org/10.1016/j.eaef.2013.12.011

Villanueva, M., Ronda, F., Moschakis, T., Lazaridou, A., \& Biliaderis, C. (2018). Impact of acidification and protein fortification on thermal properties of rice, potato and tapioca starches and rheological behaviour of their gels. Food Hydrocolloids, 79, 20-29. https://doi.org/10.1016/j.foodhyd.2017.12.022

Wang, C., Gao, F., Zhang, T. H., Wang, Y. L., \& Guo, M. R. (2015). Physiochemical, textural, sensory properties and probiotic survivability of Chinese Laosuan Nai (protein-fortified set yoghurt) using polymerised whey protein as a co-thickening agent. International Journal of Dairy Technology, 68(2), 261-269. https://doi.org/ 10.1111/1471-0307.12186

Wang, R. X., Hai, L., Zhang, X. Y., You, G. X., Yan, C. S., \& Xiao, S. H. (2009a). QTL mapping for grain filling rate and yield-related traits in RILs of the Chinese winter wheat population Heshangmai $\times$ Yu8679. Theoretical and Applied Genetics, 118, 313-325. https://doi.org/10.1007/s00122-008- 0901-5

Walton, D. A., \& Wallace, H. M. (2015). The effect of mechanical dehuskers on the quality of macadamiakernels when dehusking macadamia fruit at differing harvestmoisture contents. Scientia Horticulturae, 182, 119-123. https://doi.org/10.1016/j.scienta.2014.10.053

Wei, K. S., Yang, W. L., Jilani, G., \& Zhou, W. J. (2012). Effect of high temperature on the enzymatic activities and transcriptional expression of starch debranching enzyme (DBE) mutiple isoforms in developing rice endosperms. Journal of Animal \& Plant Sciences, 22(1), 97-107. https://doi.org/10.1080/10440046. 2012.672547

Wiset, L., Laoprasert, P., \& Borompichaichartkul, C. (2011). Effects of In-bin aeration storage on physicochemical properties and auality of glutinous rice cultivar RD6. Australian Journal of Crop Science, 5(6), 635-640. https://doi.org/10.1111/j.1445-6664.2011.00409.x

Wroblewitz, S., Hüther, L., Manderscheid, R., Weige, H., \& Danicke, S. (2014) Effect of rising atmospheric carbon dioxide concentration on the protein composition of cereal grain. Journal of Agricultural and Food Chemistry, 62(28), 6616-6625. https://doi.org/10.1021/jf501958a

Xu, H., Wei, Y., Zhu, Y. Lian, L., Xie, H., Cai, Q., ... Zhang, J. (2015). Antisense suppression of LOX3 gene expression in rice endosperm enhances seed longevity. Plant Biotechnology Journal, 13(4), 526-539. https://doi.org/10.1111/pbi.12277 
Yang, L. P., Zhou, Y. B., Wu, Y. M., Meng, X., Jiang, Y. M., Zhang, H. W., \& Wang, H. S. (2016). Preparation and physicochemical properties of three types of modified glutinous rice starches. Carbohydrate Polymers, 137, 305-313. https://doi.org/10.1016/j.carbpol.2015.10.065

Ye, G. Y., Liang, S. S., \& Wan, J. M. (2010). QTL mapping of protein content in rice using single chromosome segment substitution lines. Theoretical and Applied Genetics, 121, 741-750. https://doi.org/10.1007/ s00122-010-1345-2

Yu, S. F., Ying, M., \& Sun, D. W. (2009). Impact of amylose content on starch retrogradation and texture of cooked milled rice during storage. Journal of Cereal Science, 50(2), 139-144. https://doi.org/10.1016/j.jcs. 2009.04.003

Zabed, H., Boyce, A. N., Sahu, J. N., \& Faruq, G. (2017). Evaluation of the quality of dried distiller's grains with solubles for normal and high sugary corn genotypes during dry-grind ethanol production. Journal of Cleaner Production, 142, 4282-4293. https://doi.org/10.1016/j.jclepro.2016.11.180

Zhang, L., Fang, R., \& Sun, Z, H. (2011). Effects of rice quality by modified atmosphere packing with PA/PE composite membrane. Advanced Materials Research, 380, 274-277. https://doi.org/10.4028/www.scientific. net/AMR.217-218.274

Zhang, Y., Chen, H., Zhang, Y., Xiang, J., Ji, G. G., \& Zhu, D. F. (2017). Root morphology in response to nitrogen supply in mid-season indica rice cultivars released in different decades. Science China Life Sciences, 60(4), 1-4. https://doi.org/10.1007/s11427-016-0326-7

Zhang, Y., Wu, X. S., Wu, J. D., Yang, S. X., Tong, J. P., Zheng, L. Y., ... Wu, Y. J. (2003). Study on physical and chemical properties of rice during storage. China Grain and Oil News, 2003(6), 20-24. https://doi.org/ 10.3321/j.issn:1003-0174.2003.06.005

Zhang, Y. H., Huang, L. H., \& Wei, Z. C. (2014). Effects of additional fibrils on structural and rheological properties of rice bran albumin solution and gel. European Food Research and Technology, 239(6), 971-978. https://doi.org/10.1007/s00217-014-2294-9

Zhou, X. Q., Sun, J., Zhang, Y. R. Liu, Y., \& Gao, J. M. (2016). Relationships between three-point bending mechanical properties with cooking and edible quality of rice. Modern Food Science \& Technology, 32(6), 35-41. https://doi.org/10.13982/j.mfst.1673-9078.2016.6.007

Zhou, Z., Robards, K., Helliwell, S., \& Blanchard, C. (2002). Ageing of stored rice: changes in chemical and physical attributes. Cereal. Sci, 35, 65-78. https://doi.org/10.1006/jcrs.2001.0418

Zhou, Z., Robards, K., Helliwell, S., \& Blanchard, C. (2003). Effect of rice storage on pasting properties of rice flour. Food Research International, 36, 625-634. https://doi.org/10.1016/s0963-9969(03)00013-9

Zhou, Z., Robards, K., Helliwell, S., \& Blanchard, C. (2010). Effect of storage temperature on rice thermal properties. Food Research International, 43, 709-715. https://doi.org/10.1016/j.foodres.2009.11.002

Zhou, Z. K., Yang, X., Su, Z., \& Bu, D. D. (2016). Effect of ageing-induced changes in rice physicochemical properties on digestion behaviour following storage. Journal of Stored Products Research, 67, 13-18. https://doi.org/10.1016/j.jspr.2016.01.004

Zia, U. R. (2006). Storage effects on nutritional quality of commonly consumed cereals. Food Chemistry, 95, 53-57. https://doi.org/10.1016/j.foodchem.2004.12.017

Ziegler, V., Ferreira, C. D., Goebel, J. T., El-Halal, S. L., Santetti, G. S., Gutkoski, L. C., ... Elias, M. C. (2017). Changes in properties of starch isolated from whole rice grains with brown, black, and red pericarp after storage at different temperatures. Food Chemistry, 216, 194-200. https://doi.org/10.1016/j.foodchem. 2016.08.045

\section{Copyrights}

Copyright for this article is retained by the author(s), with first publication rights granted to the journal.

This is an open-access article distributed under the terms and conditions of the Creative Commons Attribution license (http://creativecommons.org/licenses/by/4.0/). 